\title{
Comparative Analysis of Shear Bond Strength of Steel and Ceramic Orthodontic Brackets Bonded with Six Different Orthodontic Adhesives
}

\author{
Análisis Comparativo de la Resistencia al Corte de Brackets de Ortodoncia \\ de Acero y Cerámica Unidos con Seis Adhesivos de Ortodoncia Diferentes
}

\begin{abstract}
Thiago Fonseca-Silva'; Rejane Pereira Otoni'; Ariana Alves Moraes Magalhães; Geisy Michelle Ramos; Taís Rodrigues Gomes ${ }^{1}$; Thiago Motta Rego²; Cíntia Tereza Pimenta Araújo \& Carolina Carvalho de Oliveira Santos ${ }^{1}$
\end{abstract}

FONSECA-SILVA, T.1; OTONI, R. P.; MAGALHÃES, A. A. M.; RAMOS, G. M.; GOMES, T. R.; REGO, T. M.; ARAÚJO, C. T. P. \& SANTOS, C. C. O. Comparative analysis of shear bond strength of steel and ceramic orthodontic brackets bonded with six different orthodontic adhesives. Int. J. Odontostom. 14(4):658-663, 2020.

ABSTRACT: Orthodontic accessories bonding in tooth enamel has been a critical step since the introduction of direct bonding techniques due to the importance of bracket stability. The aim of this study was to evaluate adhesion strength of different adhesive systems used for bracket bonding on dental surface. The present in vitro study was made from the analysis of shear strength of steel and ceramic brackets bonding with six different types of orthodontic adhesives. The brackets were bonded to 120 human extracted first premolar teeth with Orthocem $\AA$, Orthocem $®+$ Ambar Universal ${ }^{\circ}$ primer, Orthobond Plus $®$, Biofix $®$, Transbond $X T \AA$, Ortholink VLC®. Shear strength tests were performed on a universal testing machine EZ-Test-Shimadzu® and the data were analyzed using ANOVA test with Post-Hoc Bonferroni and $95 \%$ statistical significance $(p<0.05)$. Transbond XT® and Ortholink VLC® resin values showed greater shear resistance for steel brackets bonding and Transbond $X T \AA$ and Orthobond Plus $®$ adhesives showed better adhesion results for ceramic brackets bonding.

KEY WORDS: Adhesion; Orthodontics; Orthodontic adhesives; Shear bond strength.

\section{INTRODUCTION}

Recently, scientific and technological advancing has brought several benefits to the dentistry practical (Mondelli \& de Feitas, 2007). Research in dental materials resulted in improvement and simplification of clinical procedures, which made them faster, more efficient and more effective (Mondelli \& Feitas; Rocha et al., 2014). Since the beginning of the use of fixed apparatus in orthodontics, great attention has been given to bracket fixation and stability on the teeth (Farina et al., 2008; Bezerra et al., 2015).

The development of acid etching technique by Buonocore (1955) led to replacement of orthodontic bands by accessories direct bonding to the surface of teeth (Buonocore; Sharma et al., 2014). However, failures in bonding processes or low resistance of orthodontic adhesives can result in undesirable bracket detachments, which generate delays in treatment, inadequate biomechanical effects, patient discomfort and additional cost (Powers et al., 1997; Klocke \& KahlNieke, 2005).

Adhesive systems used for bracket bonding are a critical factor for accessory fixing on teeth (Wang et al., 2004; Henkin et al., 2016). Besides of orthodontic adhesives must be resistant and have good adhesion, they should have a working time compatible with clinical needs, be non-toxic, have a thermal expansion coefficient similar to the tooth, do not damage the tooth surface, be insoluble to oral fluids, do not suffer change in color and allow bracket removal without causing damage to enamel (Queiroz Tavares et al., 2018).

\footnotetext{
${ }^{1}$ Department of Dentistry, School of Biological and Health Sciences, Universidade Federal dos Vales do Jequitinhonha e Mucuri - UFVJM, Diamantina, MG, Brazil.

${ }^{2}$ School of Dentistry, Universidade Federal de Minas Gerais - UFMG, Belo Horizonte, MG, Brazil.
} 
Several researches related to bracket adhesion strength on the tooth have been carried out in order to create and identify the best materials capable of resisting to masticatory and orthodontic forces (Fleischmann et al., 2008; Neves et al., 2011; Hammad et al., 2017). However, in clinical practice, the range of available bonding materials is wide and information about their effectiveness is still scanty. In this context, the objective of the present work was to analyze, comparatively, shear strength of six different adhesive systems used for steel and ceramic brackets bonding on dental surface.

\section{MATERIAL AND METHOD}

Study design and sample. The present in vitro experimental study was approved by the local Research Ethics Committee under protocol number 2.663.969. 120 healthy human extracted premolar teeth, without dental enamel formation defects or coronal cracks and fractures were selected. The teeth were acquired through the Human Teeth Bank of Universidade Federal dos Vales do Jequitinhonha e Mucuri, in the city of Diamantina, Minas Gerais, Brazil.

Initially, teeth were randomly divided into two groups according to the type of bracket. After, all teeth were redistributed into groups according to the types of adhesive system used (Table I).

Preparation of specimens and shear test. The specimens were manufactured from filling PVC tubes with acrylic resin $(40 \mathrm{~mm}$ in diameter and $20 \mathrm{~mm}$ in height) followed by insertion of the dental root in the tubes for teeth fixation. Dental crowns were positioned $90^{\circ}$ with PVC tube base according to a set-square measurement. After polymerization, the specimens were kept in distilled water at $37^{\circ} \mathrm{C}$ for 72 hours (Bishara et al., 2000, 2001).
For the experiments, edgewise steel and ceramic brackets, slot .022mm (Morelli®, Sorocaba, São Paulo) for premolars were bonded in center of clinical crown of buccal teeth surfaces. Steel brackets were $3.80 \mathrm{~mm}$ in width by $3.90 \mathrm{~mm}$ in height with total base area $14.82 \mathrm{~mm}^{2}$; while the ceramics were $3.70 \mathrm{~mm}$ wide by $3.50 \mathrm{~mm}$ high and total base area was $12.95 \mathrm{~mm}^{2}$.

The specimens were cleaned and brushed with pumice paste and rubber cup (Microdont $₫$, São Paulo, São Paulo) for 10 seconds, followed by washing for 30 seconds and surface drying. Subsequently, the enamel surface was conditioned with $37 \%$ phosphoric acid (Condac $37 \circledR$, FGM, Joinville/Santa Catarina) according to the manufacturer's specifications and washed thoroughly. Teeth drying were carried out with air jets. Then, brackets were bonded with orthodontic adhesives according to manufacturers' specifications by a single operator.

For bonding performing, orthodontic adhesives were applied on bracket base, by compressing against the tooth surface and surplus was removed with a clinical probe. The photoactivation of the adhesives was carried out by a calibrated photopolymerizer (GnatusLd Max®, Ribeirão Preto, São Paulo) and it was performed for 10 seconds on each bracket face (mesial, distal, cervical and occlusal). After bonding, the specimens were stored in distilled water for 48 hours at $37^{\circ} \mathrm{C}$ until the mechanical tests.

The mechanical tests were carried out on a universal testing machine, EZ-Test-Shimadzu $₫$, with $200 \mathrm{Kgf} \mathrm{load}$ cell and speed of $0.5 \mathrm{~mm} / \mathrm{min}$ in occlusalgingival direction with an active chisel tip (Pignatta et al., 2009). The force required to take off each bracket was recorded and expressed in Newtons $(\mathrm{N})$. The results were divided by the area of the bracket base in square millimeters $\left(\mathrm{mm}^{2}\right)$ and converted into Megapascal (Mpa).
Table I. Characterization of experimental groups.

\begin{tabular}{|c|c|c|c|}
\hline Group (n) & Type of bracket & Adhesive & Manufacturer \\
\hline Group $1(n=10)$ & Steel & Orthocem ${ }^{\circledR}$ & FGM \\
\hline Group $2(n=10)$ & Steel & Orthocem $\AA+$ Ambar Universal $₫$ & FGM \\
\hline Group $3(n=10)$ & Steel & Orthobond Plus $₫$ & MORELLI \\
\hline Group $4(n=10)$ & Steel & Biofix $®$ & BIODINÂMICA \\
\hline Group $5(n=10)$ & Steel & Transbond $\mathrm{XT} \circledast$ & $3 \mathrm{M}$ \\
\hline Group $6(n=10)$ & Steel & Ortholink VLC® & ORTHOMETRIC \\
\hline Group $7(n=10)$ & Ceramic & Orthocem $®$ & FGM \\
\hline Group $8(n=10)$ & Ceramic & Orthocem $®+$ Ambar Universal ${ }^{\circledR}$ & FGM \\
\hline Group $9(n=10)$ & Ceramic & Orthobond Plus $®$ & MORELLI \\
\hline Group $10(n=10)$ & Ceramic & Biofix® & BIODINÂMICA \\
\hline Group $11(n=10)$ & Ceramic & Transbond $\mathrm{XT} \circledast$ & $3 \mathrm{M}$ \\
\hline Group $12(n=10)$ & Ceramic & Ortholink VLC® & ORTHOMETRIC \\
\hline
\end{tabular}

Data analysis. The data were tabulated in the SPSS 17.0 for Windows software. Shapiro-Wilk test was performed to verify data normality, and later, they were treated with ANOVA test with Post-hoc Bonferroni. In all tests, the level of significance was considered $95 \%$ ( $p$ $\leq 0.05$ ). 
RESULTS

Descriptive analysis of shear strength for steel brackets revealed mean values of $7.8 \pm 3.6 \mathrm{Mpa}, 11.3$ $\pm 2.7 \mathrm{Mpa}, 9.2 \pm 3.2 \mathrm{Mpa}, 12.1 \pm 6.5 \mathrm{Mpa}, 16.0 \pm 5.3 \mathrm{Mpa}$ and 16.2 $\pm 3.5 \mathrm{Mpa}$ respectively for the Orthocem $\AA$, Orthocem $\AA$ + Ambar Universal $₫$, Orthobond Plus $₫$, Biofix ${ }^{\circledR}$, Transbond $X T \AA$ and Ortholink VLC $®$. For ceramic brackets, average values were $14.3 \pm 9.3 \mathrm{Mpa}$, $12.7 \pm 2.8 \mathrm{Mpa}, 26.4 \pm 10.6 \mathrm{Mpa}, 10.0 \pm 4.5 \mathrm{Mpa}, 31.7 \pm$ $11.6 \mathrm{Mpa}$ and $20,3 \pm 7.0 \mathrm{Mpa}$ respectively for Orthocem $\AA$, Orthocem $\AA$ + Ambar Universal $₫$, Orthobond Plus $\AA$, Biofix $\AA$, Transbond $X T \AA$ and Ortholink VLC®.
Table II. Comparative analysis of shear strength between the different adhesives tested.

\begin{tabular}{|c|c|c|c|c|c|}
\hline \multirow[t]{2}{*}{ Steel brackets } & & \multirow{2}{*}{$\begin{array}{c}\text { Mean } \\
\text { Difference }\end{array}$} & \multirow[t]{2}{*}{ "p" value } & \multicolumn{2}{|c|}{ Confidence interval (95\%) } \\
\hline & & & & Minimum & Maximum \\
\hline \multirow[t]{5}{*}{ Orthocem $®$} & Orthocem $\circledast+$ Ambar ${ }^{\circledR}$ & $-3,40587111$ & 1 & $-9,8559282$ & 3,044186 \\
\hline & Orthobond Plus ${ }^{\circledR}$ & $-1,37951511$ & 1 & $-7,6662531$ & 4,9072229 \\
\hline & Biofix® & $-4,29770211$ & 0,602 & $-10,5844401$ & 1,9890359 \\
\hline & Transbond $\mathrm{XT} \circledast$ & $-8,12060611$ & 0,003 & $-14,4073441$ & $-1,8338681$ \\
\hline & Ortholink VLC® & $-8,34539986$ & 0,005 & $-14,9939665$ & $-1,6968332$ \\
\hline \multirow[t]{5}{*}{ Orthocem ${ }^{\circledR}+$ Ambar ${ }^{\circledR}$} & Orthocem $\circledast$ & 3,40587111 & 1,000 & $-3,0441860$ & 9,8559282 \\
\hline & Orthobond Plus ${ }^{\circledR}$ & 2,026356 & 1 & $-4,260382$ & 8,313094 \\
\hline & Biofix $\circledast$ & $-0,891831$ & 1 & $-7,178569$ & 5,394907 \\
\hline & Transbond XT® & $-4,714735$ & 0,374 & $-11,001473$ & 1,572003 \\
\hline & Ortholink VLC® & $-4,93952875$ & 0,394 & $-11,5880954$ & 1,7090379 \\
\hline \multirow[t]{5}{*}{ Orthobond Plus ${ }^{\circledR}$} & Orthocem ${ }^{\circledR}$ & 1,37951511 & 1 & $-4,9072229$ & 7,6662531 \\
\hline & Orthocem $\circledast+$ Ambar $®$ & $-2,026356$ & 1 & $-8,313094$ & 4,260382 \\
\hline & Biofix ${ }^{\circledR}$ & $-2,918187$ & 1 & $-9,0372484$ & 3,2008744 \\
\hline & Transbond $\mathrm{XT} \circledast$ & $-6,74109100$ & 0,02 & $-12,8601524$ & $-0,6220296$ \\
\hline & Ortholink VLC® & $-6,96588475$ & 0,026 & $-13,4561295$ & $-0,47564$ \\
\hline \multirow[t]{5}{*}{ Biofix $\circledast$} & Orthocem ${ }^{\circledR}$ & 4,29770211 & 0,602 & $-1,9890359$ & 10,5844401 \\
\hline & Orthocem $\circledast+$ Ambar $\circledast$ & 0,891831 & 1 & $-5,394907$ & 7,178569 \\
\hline & Orthobond Plus ${ }^{\circledR}$ & 2,918187 & 1 & $-3,2008744$ & 9,0372484 \\
\hline & Transbond $\mathrm{XT} \circledast$ & $-3,822904$ & 0,897 & $-9,9419654$ & 2,2961574 \\
\hline & Ortholink VLC® & $-4,04769775$ & 0,904 & $-10,5379425$ & 2,442547 \\
\hline \multirow[t]{5}{*}{ Transbond XT® } & Orthocem $\circledast$ & 8,12060611 & 0,003 & 1,8338681 & 14,4073441 \\
\hline & Orthocem $₫+$ Ambar $®$ & 4,714735 & 0,374 & $-1,572003$ & 11,001473 \\
\hline & Orthobond Plus ${ }^{\circledR}$ & 6,74109100 & 0,020 & 0,6220296 & 12,8601524 \\
\hline & Biofix® & 3,822904 & 0,897 & $-2,2961574$ & 9,9419654 \\
\hline & Ortholink VLC® & $-0,22479375$ & 1 & $-6,7150385$ & 6,265451 \\
\hline \multirow[t]{5}{*}{ Ortholink VLC® } & Orthocem ${ }^{\circledR}$ & 8,34539986 & 0,005 & 1,6968332 & 14,9939665 \\
\hline & Orthocem $\circledast+$ Ambar $\circledast$ & 4,93952875 & 0,394 & $-1,7090379$ & 11,5880954 \\
\hline & Orthobond Plus ${ }^{\circledR}$ & 6,96588475 & 0,026 & 0,47564 & 13,4561295 \\
\hline & Biofix® & 4,04769775 & 0,904 & $-2,442547$ & 10,5379425 \\
\hline & Transbond $\mathrm{XT} \circledast$ & 0,22479375 & 1 & $-6,265451$ & 6,7150385 \\
\hline \multicolumn{6}{|l|}{ Ceramic brackets } \\
\hline \multirow[t]{5}{*}{ Orthocem ${ }^{\circledR}$} & Orthocem $\circledast+$ Ambar $\circledast$ & 1,56183153 & 1,000 & $-11,3585450$ & 14,4822081 \\
\hline & Orthobond Plus ${ }^{\circledR}$ & $-12,09347822$ & 0,055 & $-24,3107013$ & 0,1237449 \\
\hline & Biofix® & 4,25030028 & 1,000 & $-8,6700763$ & 17,1706768 \\
\hline & Transbond $\mathrm{XT} \circledast$ & $-17,40332122$ & 0,001 & $-29,6205443$ & $-5,1860981$ \\
\hline & Ortholink VLC® & $-6,01032222$ & 1,000 & $-18,9306988$ & 6,9100543 \\
\hline \multirow[t]{5}{*}{ Orthocem $\circledast+$ Ambar ${ }^{\circledR}$} & Orthocem $\circledast$ & $-1,56183153$ & 1,000 & $-14,4822081$ & 11,3585450 \\
\hline & Orthobond Plus ${ }^{\circledR}$ & $-13,65530975$ & 0,024 & $-26,2680141$ & $-1,0426054$ \\
\hline & Biofix ${ }^{\circledR}$ & 2,68846875 & 1,000 & $-10,6064890$ & 15,9834265 \\
\hline & Transbond $\mathrm{XT} \circledast$ & $-18,96515275$ & 0,000 & $-31,5778571$ & $-6,3524484$ \\
\hline & Ortholink VLC® & $-7,57215375$ & 1,000 & $-20,8671115$ & 5,7228040 \\
\hline \multirow[t]{5}{*}{ Orthobond Plus ${ }^{\circledR}$} & Orthocem ${ }^{\circledR}$ & 12,09347822 & 0,055 & $-0,1237449$ & 24,3107013 \\
\hline & Orthocem $\circledast+$ Ambar $\circledast$ & 13,65530975 & 0,024 & 1,0426054 & 26,2680141 \\
\hline & Biofix® & 16,34377850 & 0,003 & 3,7310741 & 28,9564829 \\
\hline & Transbond XT® & $-5,30984300$ & 1,000 & $-17,2012147$ & 6,5815287 \\
\hline & Ortholink VLC® & 6,08315600 & 1,000 & $-6,5295484$ & 18,6958604 \\
\hline \multirow[t]{5}{*}{ Biofix $\circledast$} & Orthocem ${ }^{\circledR}$ & $-4,25030028$ & 1,000 & $-17,1706768$ & 8,6700763 \\
\hline & Orthocem $\circledast+$ Ambar $\circledast$ & $-2,68846875$ & 1,000 & $-15,9834265$ & 10,6064890 \\
\hline & Orthobond Plus ${ }^{\circledR}$ & $-16,34377850$ & 0,003 & $-28,9564829$ & $-3,7310741$ \\
\hline & Transbond $\mathrm{XT} \circledast$ & $-21,65362150$ & 0,000 & $-34,2663259$ & $-9,0409171$ \\
\hline & Ortholink VLC® & $-10,26062250$ & 0,316 & $-23,5555803$ & 3,0343353 \\
\hline Transbond $\mathrm{XT} \circledast$ & Orthocem ${ }^{\circledR}$ & 17,40332122 & 0,001 & 5,1860981 & 29,6205443 \\
\hline & Orthocem $\circledast+$ Ambar ${ }^{\circledR}$ & 18,96515275 & 0,000 & 6,3524484 & 31,5778571 \\
\hline & Orthobond Plus ${ }^{\circledR}$ & 5,30984300 & 1,000 & $-6,5815287$ & 17,2012147 \\
\hline & Biofix® & 21,65362150 & 0,000 & 9,0409171 & 34,2663259 \\
\hline & Ortholink VLC $\circledast$ & 11,39299900 & 0,113 & $-1,2197054$ & 24,0057034 \\
\hline Ortholink VLC® & Orthocem ${ }^{\circledR}$ & 6,01032222 & 1,000 & $-6,9100543$ & 18,9306988 \\
\hline & Orthocem $\circledast+$ Ambar $\circledast$ & 7,57215375 & 1,000 & $-5,7228040$ & 20,8671115 \\
\hline & Orthobond Plus ${ }^{\circledR}$ & $-6,08315600$ & 1,000 & $-18,6958604$ & 6,5295484 \\
\hline & Biofix® & 10,26062250 & 0,316 & $-3,0343353$ & 23,5555803 \\
\hline & Transbond $\mathrm{XT} \circledast$ & $-11,39299900$ & 0,113 & $-24,0057034$ & 1,2197054 \\
\hline
\end{tabular}

The results of comparative analysis of shear strength were shown in Table II. For steel brackets, Transbond XT $\circledast$ and Ortholink VLC $₫$ adhesives showed better values when compared to Orthocem ${ }^{\circledR}$ and Orthobond Plus ${ }^{\circledR}(p<0.05)$. Other comparisons did not show statistically significant differences. For ceramic brackets, Transbond XT® adhesive showed superior results when compared to Orthocem $\AA$, Orthocem $\AA+$ Ambar Universal $\AA^{\circledR}$ and Biofix $\circledast(p<0.05)$. Additionally, Orthobond Plus $®$ showed better results when compared to Orthocem $\AA$ + Ambar Universal ${ }^{\circledR}$ and Biofix ${ }^{\circledR}(p<0.05)$. Other comparisons did not show statistically significant differences.

\section{DISCUSSION}

In the present study, it was observed that Transbond XT® and Ortholink VLC $®$ resin presented higher shear resistance for bonding steel brackets. Additionally, Transbond $\mathrm{XT} \circledast$ and Orthobond Plus ${ }^{\circledR}$ adhesives showed better adhesion results for ceramic brackets bonding.

Some researches related to orthodontic adhesives has described superior shear results of Transbond $\mathrm{XT} \otimes$ in comparison to other materials for brackets bonding (Romano et al., 2005; Kumar et al., 2011; Lima et al., 2015). However, the factors that result in improved adhesion of Transbond $X T ®$ are still unknown. It is also unclear which factors are related to the better performance of Orthobond Plus ${ }^{\circledR}$ and Ortholink VLC $\circledast$ adhesives. It is suggested that characteristics such as resin curing time, paste translucency and chemical composition could determinate 
FONSECA-SILVA, T.1; OTONI, R. P.; MAGALHÃES, A. A. M.; RAMOS, G. M.; GOMES, T. R.; REGO, T. M.; ARAÚJO, C. T. P. \& SANTOS, C. C. O. Comparative analysis of shear bond strength of steel and ceramic orthodontic brackets bonded with six different orthodontic adhesives. Int. J. Odontostom. 14(4):658-663, 2020.

superior performance of these systems (Klocke \& Kahl-Nieke, 2006; Yamamoto et al., 2006; Finnema et al., 2010).

Shear strength studies for bracket bonding indicate that forces between 5.0 and 7.9Mpa are considered clinically acceptable (Reynolds, 1975; Reicheneder et al., 2009). In this context, all tested adhesives in the present study showed shear strength values over than $7.8 \mathrm{Mpa}$, which characterizes them as clinically adequate for bonding of orthodontic brackets. However, the results of shear bond strength of orthodontic resins are quite heterogeneous and commonly divergent. The lack of standardized parameters for adhesion resistance analysis of orthodontic resins results in a limited comparison of results among the previous studies. Factors such as type of tooth, adhesion surface (buccal or lingual), enamel chemical composition, shape of bracket base, surface contamination and photopolymerization time can affect in vitro tests results and generate data dispersion (Al Qahtani et al., 2010; Scribante et al., 2013; Hattar et al., 2014, 2015).

The resin/tooth adhesion process is related to the morphological enamel structure and adhesive chemical composition, which are determined by depth and thickness of the projections of adhesive layers on dental surface (Guan et al., 1998). Thus, the strength of resin adhesion to the tooth will always be individualized and difficult to standardize clinically. Besides of this, in the oral cavity, humidity and temperature variations tend to influence the stability of orthodontic brackets adhesion. These factors must be considered because environmental changes can influence physical properties of polymeric materials, especially rheological characteristics, mechanical rigidity and hardness (Min et al., 1993; Haydar et al., 1999; Pithon et al., 2007; Feldon et al., 2010).

In addition, the resistance force seems to be influenced by bracket material. Ceramic and steel brackets may have different adhesion interactions when the same adhesive systems are used. In this context, literature highlights that ceramic brackets have significantly higher resistance levels than steel devices, requiring greater shearing force for their removal (Joseph \& Rossouw, 1990; Haydar et al.; Rocha et al. ). Such condition may be related to photoactivation effectiveness of orthodontic adhesives when ceramic brackets are used. Light penetration is more effective in ceramic materials when compared to steel ones, due to translucency of ceramic materials, which consequently enhance the complete adhesive polymerization (Joseph \& Rossouw; Haydar et al.; Mattos et al., 2006; Feldon et al.; Rocha et al. ). Our results suggest that shear force for ceramic brackets removal is greater than for the steel ones.

The use of Orthocem ${ }^{\circledR}$ resin with and without Ambar Universal ${ }^{\circledR}$ primer did not generate significant differences in adhesion strength, confirming the manufacturer's recommendation that orthodontic resin paste can be used alone. This finding can be corroborated by other studies that also did not find statistical differences in the shear strength of bonded brackets with or without use of bonding primers (Moin \& Dogon, 1977; Jassem et al., 1981; Farquhar, 1986; Neves et al. ).

Besides of different properties of orthodontic adhesives and diverse brackets materials, others factors can contribute to heterogeneous shear strength results of orthodontic resins. According to Klocke \& Kahl-Nieke (2005) extracted human teeth can undergo changes due to handling and storage prior to the experiment and, consequently, modify the surface adhesion energy (Klocke \& Kahl-Nieke, 2005). In this sense, consecutive dehydration and rehydration phenomena could negatively interfere in extracted teeth experimentation model, resulting in important variations in research results.

At real clinical conditions, composites suffer degradation in the mouth through the action of salivary components, deleterious habits, chewing, feeding and temperature (Murray \& Hobson, 2003). Due to it, more robust studies are needed simulating real oral clinical conditions. It is important to highlight that the present in vitro study has its design as a limitation and the results could not be extrapolated to clinical practice. In this sense, more studies are needed to better comprehension of clinical use of orthodontic adhesives.

\section{CONCLUSION}

It is concluded that Transbond $X T \AA$ and Ortholink VLC ${ }^{\circledR}$ showed higher shear resistance for steel brackets bonding and that Transbond $\mathrm{XT} \otimes$ and Orthobond Plus ${ }^{\circledR}$ adhesives showed better adhesion results for ceramic brackets bonding. 


\section{ACKNOWLEDGMENTS}

This study was supported by the Universidade Federal dos Vales do Jequitinhonha e Mucuri (UFVJM) and the manufacturers of orthodontics products MORELLI, ORTHOMETRIC, FGM, BIODINÂMICA.

FONSECA-SILVA, T.1; OTONI, R. P.; MAGALHÃES, A. A. M.; RAMOS, G. M.; GOMES, T. R.; REGO, T. M.; ARAÚJO, C. T. P. \& SANTOS, C. C. O. Análisis comparativo de la resistencia al corte de brackets de ortodoncia de acero y cerámica unidos con seis adhesivos de ortodoncia diferentes. Int. J. Odontostmat., 14(4):658-663, 2020.

RESUMEN: La unión de accesorios de ortodoncia en el esmalte dental ha sido un paso crítico desde la introducción de las técnicas de unión directa debido a la importancia de la estabilidad del soporte. El objetivo de este estudio fue evaluar la fuerza de adhesión de diferentes sistemas adhesivos utilizados para la unión de brackets en la superficie dental. El presente estudio in vitro se realizó a partir del análisis de la resistencia al corte de brackets de acero y de cerámica unidos con seis tipos diferentes de adhesivos de ortodoncia. Los brackets se unieron a 120 primeros premolares extraídos con los adhesivos Orthocem $\AA$, Orthocem $\AA$ + Ambar Universal $₫$ primer, Orthobond Plus $\AA$, Biofix ${ }^{\circledR}$, Transbond $X T \AA$, Ortholink VLC $\AA$. Las pruebas de resistencia al corte se realizaron en una máquina de prueba universal EZ-Test-Shimadzu® y los datos se analizaron usando la prueba ANOVA con Bonferroni Post-Hoc y $95 \%$ de significación estadística $(p<0,05)$. Los valores de resina Transbond XT® y Ortholink VLC® mostraron una mayor resistencia al corte para la unión de brackets de acero y los adhesivos Transbond XT® y Orthobond Plus ${ }^{\circledR}$ mostraron mejores resultados de adhesión para la unión de brackets cerámicos.

PALABRAS CLAVE: adhesión, adhesivos de ortodoncia, ortodoncia; resistencia al cizallamiento.

\section{REFERENCES}

Al Qahtani, M. Q. \& Al Shethri, S. E. Shear bond strength of onestep self-etch adhesives with different co-solvent ingredients to dry or moist dentin. Saudi Dent. J., 22(4):171-5, 2010.

Bezerra, G. L.; Torres, C. R. G.; Tonetto, M. R.; Borges, A. H.; Kuga, M. C.; Bandeca, M. C. \& Firoozmand, L. M. Shear bond strength of orthodontic brackets fixed with remineralizing adhesive systems after simulating one year of orthodontic treatment. Scientific World Journal, 2015:903451, 2015.

Bishara, S. E.; Vonwald, L.; Laffoon, J. F. \& Warren, J. J. Effect of a self-etch primer/adhesive on the shear bond strength of orthodontic brackets. Am. J. Orthod. Dentofacial Orthop., 119(6):621-624. 2001.
Bishara, S. E.; VonWald, L.; Laffoon, J. F. \& Warren, J. J. The effect of repeated bonding on the shear bond strength of a composite resin orthodontic adhesive. Angle Orthod., 70(6):435-43. 2000.

Buonocore, M. G. A simple method of increasing the adhesion of acrylic filling materials to enamel surfaces. J. Dent. Res., 34(6):849-53, 1955.

Farina, A. P.; Cecchin, D. \& Woitchunas, D. R. Resistência de união de brackets ortodônticos ao esmalte dental usando diferentes sistemas adesivos. Rev. Fac. Odontolo. Univ. Passo Fundo, 13(1):55-9, 2008.

Farquhar, R. B. Direct bonding comparing a polyacrylic acid and a phosphoric acid technique. Am. J. Orthod. Dentofacial Orthop., 90(3):187-94, 1986.

Feldon, P. J.; Murray, P. E.; Burch, J. G.; Meister, M. \& Freedman, M. A. Diode laser debonding of ceramic brackets. Am. J. Orthod. Dentofacial Orthop., 138(4):458-62. 2010.

Finnema, K. J.; Ozcan, M.; Post, W. J.; Ren, Y. \& Dijkstra, P. U. Invitro orthodontic bond strength testing: a systematic review and meta-analysis. Am. J. Orthod. Dentofacial Orthop., 137(5):615622.e3, 2010.

Fleischmann, L. A.; Sobral, M. C.; Santos Júnior, G. C. \& Habib, F. Estudo comparativo de seis tipos de braquetes ortodônticos quanto à força de adesão. Rev. Dent. Press Ortod. Ortop. Facial, 13(4):107-16, 2008.

Guan, G.; Asai, Y.; Matasa, C. G.; Hattori, T. \& Matani, S. Resistência da colagem em relação à interface esmalte-adesivo. Rev. Dent. Press Ortod. Ortop. Facial, 3(3):93-9, 1998.

Hammad, S. M.; El-Wassefy, N.; Maher, A. \& Fawakerji, S. M. Effect of nanotechnology in self-etch bonding systems on the shear bond strength of stainless steel orthodontic brackets. Dent. Press J. Orthod., 22:47-56, 2017.

Hattar, S.; Hatamleh, M. M.; Sawair, F. \& Al-Rabab'ah, M. Bond strength of self-adhesive resin cements to tooth structure. Saudi Dent. J., 27(2):70-4, 2015.

Hattar, S.; Hatamleh, M.; Khraisat, A. \& Al-Rabab'ah, M. Shear bond strength of self-adhesive resin cements to base metal alloy. J. Prosthet. Dent., 111(5):411-5, 2014.

Haydar, B.; Sarikaya, S. \& Cehreli, Z. C. Comparison of shear bond strength of three bonding agents with metal and ceramic brackets. Angle Orthod., 69(5):457-62, 1999.

Henkin, F. S.; Macêdo, É. O. D.; Santos, K. D. S.; Schwarzbach, M.; Samuel, S. M. W. \& Mundstock, K. S. In vitro analysis of shear bond strength and adhesive remnant index of different metal brackets. Dent. Press J. Orthod., 21(6):67-73, 2016.

Jassem, H. A.; Retief, D. H. \& Jamison, H. C. Tensile and shear strengths of bonded and rebonded orthodontic attachments. Am. J. Orthod., 79(6):661-8, 1981.

Joseph, V. P. \& Rossouw, E. The shear bond strengths of stainless steel and ceramic brackets used with chemically and lightactivated composite resins. Am. J. Orthod. Dentofacial Orthop., 97(2):121-5, 1990.

Klocke, A. \& Kahl-Nieke, B. Effect of debonding force direction on orthodontic shear bond strength. Am. J. Orthod. Dentofacial Orthop., 129(2):261-5, 2006.

Klocke, A. \& Kahl-Nieke, B. Influence of force location in orthodontic shear bond strength testing. Dent. Mater., 21(5):391-6, 2005.

Kumar, R. R.; Kaur, M. \& Miglani, A. Contemporary orthodontic bonding adhesives - An in vitro Study. J. Pierre Fauchard Acad., 25(3):144-8, 2011.

Lima, L. M.; Valdrighi, H. C.; Correa, C. A.; Lealdini, L. N. \& Venezian, G. C. Influência da resina para colagem na resistência ao cisalhamento de bráqutes ao esmalte bovino. UNOPAR Cient. Cienc. Biol. Saude, 17(3):198-202, 2015.

Mattos, A. M. \& Capelli Júnior, J. Avaliação da superfície da porcelana após a descolagem de braquetes ortodônticos. Rev. Dent. Press Ortod. Ortop. Facial, 11(5):151-8, 2006. 
Min, B. G.; Stachurski, Z. H. \& Hodgkin, J. H. Cure kinetics of elementary reactions of a DGEBA/DDS epoxy resin: 1 . Glass transition temperature versus conversion. Polymer, 34(23):490812, 1993.

Moin, K. \& Dogon, I. L. Indirect bonding of orthodontic attachments. Am. J. Orthod., 72(3):261-75, 1977.

Mondelli, A. L. \& de Feitas, M. R. Estudo comparativo da resistência adesiva da interface resina/braquete, sob esforços de cisalhamento, empregando três resinas compostas e três tipos de tratamento na base do braquete. Rev. Dent. Press Ortod. Ortop. Facial, 12(3):111-25, 2007.

Murray, S. D. \& Hobson, R. S. Comparison of in vivo and in vitro shear bond strength. Am. J. Orthod. Dentofacial Orthop., 123(1):2-9, 2003.

Neves, A. M.; Romano, F. L. \& Correr, A. B. Shear bond strength of Concise and Transbond XT composites with and without bonding agent. Dent. Press J. Orthod., 16(6):63-8, 2011.

Pignatta, L. M. B.; Lugato, I. C. P. T.; Bertoz, F. A. \& Santos, E. C. A. Avaliação do Índice de Remanescente Adesivo utilizando braquetes com e sem tratamento na base e a interação com três sistemas de colagem. Rev. Dent. Press Ortod. Ortop. Facial, 14(1):117-23, 2009.

Pithon, M. M.; de Oliveira, M. V.; Ruellas, A. C. O.; Bolognese, A. M. \& Romano, F. L. Shear bond strength of orthodontic brackets to enamel under different surface treatment conditions. J. Appl. Oral Sci., 15(2):127-30, 2007.

Powers, J. M.; Kim, H. B. \& Turner, D. S. Orthodontic adhesives and bond strength testing. Semin. Orthod., 3(3):147, 1997.

Queiroz Tavares, M. L.; Elias, C. N. \& Nojima, L. I. Effects of different primers on indirect orthodontic bonding: Shear bond strength, color change, and enamel roughness. Korean J. Orthod., 48(4):245-52, 2018.

Reicheneder, C. A.; Gedrange, T.; Lange, A.; Baumert, U. \& Proff, P. Shear and tensile bond strength comparison of various contemporary orthodontic adhesive systems: an in-vitro study. Am. J. Orthod. Dentofacial Orthop., 135(4):422.e1-6. 2009.

Reynolds, I. R. A review of direct orthodontic bonding. Br. J. Orthod., 2(3):171-8, 1975.

Rocha, J. M. D.; Gravina, M. A.; Campos, M. J. D. S.; Quintão, C. C. A.; Elias, C. N. \& Vitral, R. W. F. Shear bond resistance and enamel surface comparison after the bonding and debonding of ceramic and metallic brackets. Dent. Press J. Orthod., 19(1):7785, 2014.

Romano, F. L.; Tavares, S. W.; Nouer, D. F.; Consani, S. \& Borges de Araújo Magnani, M. B. Shear bond strength of metallic orthodontic brackets bonded to enamel prepared with SelfEtching Primer. Angle Orthod., 75(5):849, 2005.

Scribante, A.; Sfondrini, M. F.; Fraticelli, D.; Daina, P.; Tamagnone, A. \& Gandini, P. The influence of no-primer adhesives and anchor pylons bracket bases on shear bond strength of orthodontic brackets. Biomed. Res. Int., 2013:315023, 2013.

Sharma, S.; Tandon, P.; Nagar, A.; Singh, G. P.; Singh, A. \& Chugh, V. K. A comparison of shear bond strength of orthodontic brackets bonded with four different orthodontic adhesives. J. Orthod. Sci., 3(2):29-33, 2014.

Wang, W. N.; Li, C. H.; Chou, T. H.; Wang, D. D. H.; Lin, L. H. \& Lin, C. T. Bond strength of various bracket base designs. Am. J. Orthod. Dentofacial Orthop., 125(1):65-70, 2004.

Yamamoto, A.; Yoshida, T.; Tsubota, K.; Takamizawa, T.; Kurokawa, H. \& Miyazaki, M. Orthodontic bracket bonding: enamel bond strength vs time. Am. J. Orthod. Dentofacial Orthop., 130(4):435.e1-6, 2006.
Corresponding author:

Prof. Dr. Thiago Fonseca-Silva

D.D.S.; M.Sc., Ph.D.

Department of Dentistry; Division of Orthodontics

School of Biological and Health Sciences

Universidade Federal dos Vales do Jequitinhonha e Muciri

Rua da Glória, 187 - Diamantina

Minas Gerais, Zip Code: 39100-000

BRAZIL

E-mail: thiagofonsecasilva@gmail.com

Received: 13-04-2020

Accepted: 11-07-2020 